\title{
A VIDA É A MARGEM: \\ A VIOLÊNCIA NO ROMANCE DE JOSUÉ LUZ
}

\author{
LIFE IS THE MARGIN: \\ VIOLENCE IN JOSUÉ LUZ NOVEL
}

DOI 10.20873/uft2179-3948.2021v12n1p118-137

\section{Márcio Araujo de Melo ${ }^{1}$ Andreia Nascimento Carmo ${ }^{2}$}

\begin{abstract}
Resumo: Neste artigo, apresentamos um exercício analítico das discursividades versadas sobre as violências no romance $A$ vida é a margem, de Josué Luz. O nosso objetivo principal é mostrar a maneira como algumas formas de violência estão sendo simbolizadas no/pelo romance em tela concebido, neste trabalho, como dispositivo de arquivo. Nesse sentido, buscamos dar visibilidade ao funcionamento das discursividades concernentes à violência no campo, à violência contra os homossexuais e à violência contra a mulher. Para fundamentarmos nossa análise, de maneira profícua, tomamos como aporte teórico-metodológico a Análise de Discurso francesa (AD) de base pecheuxtiana. Em nosso trabalho, observamos que na composição do texto, mesmo compreendido como arquivo, o modo como ele é constituído provoca movimentos de leitura-interpretação em que não há neutralidade. Isto é, na composição do arquivo há gestos de leitura subjacentes (PÊCHEUX, 2014[1982]).
\end{abstract}

Palavras-chave: Literatura; Arquivo; Violência; Efeitos de sentidos

\begin{abstract}
In this article, we present an analytical exercise of the discursivities versed on the violence in the novel Life is the margin, by Josué Luz. Our main objective is to show the way in which some forms of violence are being symbolized in / by the novel on screen conceived, in this work, as a file device. In this sense, we seek to give visibility to the functioning of discursivities concerning violence in the countryside, violence against homosexuals and violence against women. To support our analysis, in a fruitful way, we used the French Discourse Analysis (DA) with a pecheuxtian basis as theoretical and methodological support. In our work, we observed that in the composition of the text, even understood as an archive, the way it is constituted causes reading-interpretation movements in which there is no neutrality. That is, in the composition of the archive there are underlying reading gestures (PECCHEUX, 2014[1982]).
\end{abstract}

Keywords: Literature; Archive; Violence; Senses effects

\footnotetext{
${ }^{1}$ Doutor em Estudos Literários pela UFMG, professor adjunto da Universidade Federal do Tocantins. Coordenador do Programa de Pós-Graduação em Letras: ensino de língua e literatura. E-mail: marciodemelo33@ gmail.com

${ }^{2}$ Doutoranda em Letras pela Universidade Federal do Tocantins. Mestre em Ensino Língua e Literatura pela Universidade Federal do Tocantins; Graduação em Letras - Português e Inglês e Respectivas Literaturas pela Universidade Federal do Tocantins. Professora de Língua Portuguesa e Inglesa do Ensino Fundamental e do Médio pela Secretaria de Educação e Cultura do Tocantins.
} 


\section{Introdução}

Me apraz é que o pessoal, hoje em dia, é bom de coração. Isto é, bom no trivial. Malícias maluqueiras, e perversidades, sempre tem alguma, mas escasseadas. Geração minha, verdadeira, ainda não eram assim. Ah, vai vir um tempo, em que não se usa matar gente... Eu, já estou velho.

João Guimarães Rosa, Grande sertão: veredas.

No cenário mundial, a violência é constituída das mais variadas formas. Nessa conjuntura, iniciamos este trabalho insistindo em registrar a violência com que parte da população brasileira tem sofrido nos últimos tempos. A marca do atual governo do nosso país tem sido o desmonte de programas sociais que valorizam os mais carentes como, por exemplo, o Bolsa Família, bem como ataques às Instituições essenciais para aqueles que precisam de assistência, tais como o SUS. Registramos, ainda, o ódio que se tem criado, por parte desse governo, à escola pública, em todos os níveis da escolarização. A ausência do FUNDEB abre vias para a produção de um caos na escola básica; a ausência de investimentos nas Instituições Federais de Ensino Superior, retirando bolsas da graduação e pós-graduação, constitui a prova de um sucateamento evidente. Vivemos recentemente a possibilidade de exclusão das bolsas de PIBIC para área da Ciências Humanas.

Lembramos ainda, no que concerne às minorias, que esse governo tem construído um verdadeiro "gabinete" da violência contra os negros, os homossexuais, os trabalhadores, os migrantes etc., de modo que em certas condições, essa violência se apresenta naturalizada nas e pelas relações sociais. Enfim, há um discurso violento contra a diversidade e a diferença, contra a resistência e a luta dos mais desabastados. É nessa conjuntura que apresentamos, neste artigo, o modo como algumas representações da violência no Brasil estão circunscritas no texto literário. Especialmente, buscamos mostrar a maneira como algumas formas de violência estão sendo simbolizadas no/pelo romance $A$ vida é a margem, de Josué Luz. Sendo assim, a narrativa que nos prende a essa análise apresenta, como pano de fundo, situações demarcadas em discursividades que a memória trabalha discursos que apresentam tomadas de posição machistas, homofóbicas, enfim, violentas. Em suma, são tomadas de posição que vão ao encontro da hostilidade demonstrada pelas atitudes dos personagens.

Dessa maneira, filiados ao dispositivo teórico-metodológico que nos suporta, a Análise de Discurso pecheuxtiana (AD), tencionamos investigar como ocorre o funcionamento discursivo da raiz que constitui o nosso corpus em análise: as discursividades em que se 
engendram discursos de violência, à medida que tecemos algumas considerações sobre como essas discursividades são tomadas de maneira legitimada. Isto é, como elas são concebidas com valor de verdade para determinados grupos sociais.

Em nossos gestos de leitura-interpretação, assumimos a violência, sobretudo, a violência no campo, como o mote principal do romance, A vida é a margem, de Josué Luz. No decorrer da narrativa as ações violentas podem ser circunscritas pelo desenvolvimento do enredo que compõe toda a história. A narrativa apresenta discursividades constituídas pelo discurso de violência, tais como a violência no campo, nas estruturas sociais, a violência contra os homossexuais e as mulheres. Paralelamente, o texto de Josué Luz também apresenta a resistência e a luta em oposição a esses modos opressores.

De maneira geral, a violência é uma das temáticas mais recorrentes na literatura escrita por autores(as) do Tocantins. Consideramos que é possível estender esse mote, pois a literatura brasileira - sobretudo a que foi classificada como regional - tem insistido em produzir narrativas que trazem representações da violência no campo. Para ressaltar poucos e conhecidos exemplos, citamos Grande sertão: veredas, de Guimarães Rosa; São Bernardo, de Graciliano Ramos; O tronco, de Bernardo Élis. Assim como no romance de Josué Luz, a luta pelo poder e a resistência estão presentes nessas obras. A voz das minorias, tantas vezes silenciadas, ora e outra explode no texto. Destacamos, para ilustração, o suicídio de Madalena, compreendendo que ele é o grito de todas as mulheres contra a opressão masculina.

Para direcionarmo-nos ao foco principal deste trabalho, tomamos, dentro da perspectiva da $\mathrm{AD}$ de orientação pecheuxtiana, o romance como um dispositivo de arquivo, à medida que o concebemos, ancorados em Pêcheux (2014[1982], p. 59), como “"campo de documentos pertinentes e disponíveis sobre uma questão"'. Nesse sentido, compreendemos que o romance possui uma organização própria, determinando pela memória discursiva, gestos de leitura que (re)produzem efeitos de sentidos, consoante às suas condições de (re)exploração. Dito de outra maneira, é a memória que vai definir o que o arquivo reconhece como (in)válido. Desse modo, ressaltamos que a obra, reconhecida como dispositivo de arquivo, institui-se como um espaço heterogêneo de investigação.

Pelo ponto de vista discursivo, entendemos que a memória discursiva diz respeito àquilo que o sujeito consegue "acionar" dentro de determinado repertório discursivo, o interdiscurso. Isto é, a memória (restrita) diz respeito à posição que o sujeito assume a partir do interdiscurso (amplo). Por esse viés, salientamos que os sentidos, assim como a linguagem, não são transparentes. Eles não são dados a priori. Os sentidos são constituídos ideologicamente. Nessa 
esteira, as formações ideológicas são representadas pelas formações discursivas, que por sua vez, "determinam o que pode e deve ser dito" (PÊCHEUX, 2014[1975], p. 147). Nessa circunscrição, reiteramos que o arquivo se configura como instrumento de circulação de texto importante sobre determinados assuntos, mas que deve ser considerado, também, pela sua opacidade.

Em vista disso, importa-nos destacar que concebemos a leitura como gestos de interpretação pelos quais o sujeito inserido em determinado lugar social vai constituindo efeitos de sentidos em relação ao texto ${ }^{3}$. A partir desse entendimento, ressaltamos que para produzir sentidos, o sujeito "aciona" a memória discursiva em um dado momento de maneira involuntária. Dessa forma, podemos entender que os sentidos são linguísticos e, também, são históricos. Em outras palavras, os sentidos são articulados em dadas condições de sua produção, as quais, de acordo com Orlandi (2015), compreendem os sujeitos, a situação e a memória. É nessa medida que compreendemos que o arquivo faz trabalhar a memória social e histórica reconstruída pela escrita em uma dada conjuntura.

Sem perder de vista a noção de arquivo constituído como "um espaço polêmico das maneiras de ler" (PÊCHEUX, 2014[1982], p. 59, grifos do autor), apreendemos o arquivo como um trabalho de leitura que institui memória histórica de uma sociedade. Em vista disso, consideramos a existência de certa "imposição" atravessada pelo funcionamento ideológico, direcionada para o estabelecimento da cristalização dos sentidos. Há, segundo Pêncheux (2014[1982], p. 61, grifos do autor), uma “divisão social do trabalho da leitura”, por meio da qual, na instância das instituições sociais de poder, constitui-se uma memória histórica em que se deixa escapar determinados sentidos, perante a pluralidade de gestos de interpretação, em função de se deixar "ver" outros sentidos desejáveis. Assim, a materialidade linguísticodiscursiva do arquivo está para além do que pode ser descrito pela percepção observada, a priori, pela ilusão da transparência da linguagem.

Expressas nossas considerações iniciais, retomando a narrativa $A$ vida é a margem, almejamos apresentar possíveis gestos de leitura-interpretação a partir desse romance, a fim de evidenciarmos, por meio de determinadas discursividades que notabilizamos no decorrer da narrativa, as representações de discursos de violência. Por conseguinte, direcionamos o nosso olhar para as condições dos modos de inscrição do discurso da violência na sociedade brasileira,

\footnotetext{
${ }^{3}$ Neste trabalho, concebemos, juntamente com Indursky (2011), a noção de texto como forma material que dá suporte ao discurso. Assim, texto é por nós compreendido, "como o suporte através do qual um discurso se materializa, podendo ser tal suporte verbal ou não-verbal”. (Cf. INDURSKY, 2011, p. 76).
} 
especialmente "nos confins do sertão" do Tocantins (LUZ, 2006, p. 19). Assim, propomos analisar o funcionamento das discursividades sobre a violência no campo, a violência contra os homossexuais e a violência contra a mulher, à luz da Análise de Discurso preconizada por Pêcheux.

\section{Pela perspectiva de uma rede conceitual discursiva}

Consoante ao que já mencionamos no tópico anterior, concebemos, para o exercício analítico desenvolvido neste trabalho, algumas noções conceituais oriundas do aporte teóricometodológico pelo qual nos fundamentamos, a $\mathrm{AD}$ de base pecheuxtiana. Por esse viés, interessa-nos destacar que a produção de gestos de leitura-interpretação é construída socialmente. Desse modo, para que haja sentido, é fundamental que também haja sujeito e uma rede de sentidos com os quais ele se identifique. Essa identificação se dá pelo processo de interpelação ideológica do indivíduo em sujeito. De modo sintetizado, ser sujeito, na AD, é tomar posição. É nessa tomada de posição do sujeito que ele "aciona" a memória discursiva abarcada pelo interdiscurso instituído por múltiplas formações discursivas (FD).

Dessa maneira, visto que a FD é "aquilo que, numa formação ideológica dada, isto é, a partir de uma posição dada numa conjuntura dada, determinado pelo estado da luta de classes, determina o que pode e deve ser dito" (PÊCHEUX, 2014[1975], p. 147, grifos do autor), cabe destacar que a FD também determina o que não pode e não deve ser dito. Desse modo, entendemos que ela norteia os sentidos. Em outras palavras, a FD estabelece a produção de determinados sentidos em detrimento de outros. Nessa esteira, corroboramos com Indursky (2011, p. 87), quando a autora aponta que "uma FD é regulada por uma memória discursiva", isto é, ela corresponde à "memória discursiva que é da ordem ideológica".

Segundo Pêcheux (2015[1983], p. 46), “a memória discursiva seria aquilo que, face a um texto que surge como acontecimento a ler, vem restabelecer os 'implícitos' (quer dizer, mais tecnicamente, os pré-construídos, elementos citados e relatados, discursos transversos, etc.)”. Neste ponto, destacamos que a memória discursiva é lacunar. Ela se circunscreve àquilo que está permitido pelas FD, assim, ela é ideologicamente restrita. A memória discursiva está contida no interior do interdiscurso. O interdiscurso, por sua vez, é constituído por todos os dizeres já produzidos antes, alhures. De acordo com Indursky (2011, p. 86), “o interdiscurso constitui-se de um complexo de formações discursivas”, portanto, ele compreende uma memória totalizante, saturada. 
Diante dessas considerações, compreendemos que os efeitos de sentidos são instituídos ideologicamente e, segundo Orlandi (2015, p. 41), esse processo está na “discursividade, isto é, na maneira como, no discurso, a ideologia produz seus efeitos, materializando-se nele". Por essa perspectiva, é possível elucidar que a produção dos sentidos se sustenta pelos processos discursivos em que eles se materializam. Segundo Orlandi (2012), esses processos suscitam três momentos relevantes. Consideramos, a seguir as palavras da própria autora:

[o]s processos de produção do discurso implicam três momentos igualmente relevantes:

1. Sua constituição, a partir da memória do dizer, fazendo intervir o contexto históricoideológico mais amplo;

2. Sua formulação, em condições de produção e circunstâncias de enunciação específicas e

3. Sua circulação que se dá em certa conjuntura e segundo certas condições. (ORLANDI, 2012, p. 09).

Como podemos observar pelo excerto acima, os processos de produção do discurso são instituídos pelos momentos da constituição, da formulação e a da circulação. Ainda de acordo com Orlandi (2012), o primeiro sucede a partir do interdiscurso, a memória do dizer (eixo vertical); o segundo está na ordem do intradiscurso, em que "novas" formulações atualizam o dizer (eixo horizontal); o terceiro diz respeito aos meios em que os discursos circulam (possibilidades do dizer). Outra questão que deve ser levada em conta no âmbito da produção de sentidos é o lugar social ocupado pelos sujeitos e isso implica olhar para a divisão social de classes. Nas palavras de Pêcheux:

(...) o que funciona nos processos discursivos é uma série de formações imaginárias que designam o lugar de A e B se atribuem cada um a si e ao outro, a imagem que eles se fazem do seu próprio lugar e do lugar do outro. Se assim ocorre, existem nos mecanismos de qualquer formação social regras de projeção, que estabelecem as relações entre as situações (objetivamente definíveis) e as posições (representações dessas situações) (PÊCHEUX, 2014[1969], p. 81-82).

No movimento entre memória (interdiscurso), intradiscurso, lugar social dos sujeitos, oportunizam-se as possibilidades do dizer. Esse movimento é afetado pela história e mediado pela linguagem. Nesse sentido, a relação do arquivo com a linguagem dá-se no entremeio da relação desses dois primeiros com o discurso. Neste espaço, ressaltamos o discurso como "efeito de sentidos" (PÊCHEUX, 2014[1969], p. 81) entre interlocutores. Sendo assim, destacamos a pertinência de se considerar a opacidade constitutiva da linguagem e do dispositivo de arquivo.

É desse modo que estamos acentuando a violência: como processo discursivo e, assim, apreendendo o romance $A$ vida é a margem constituído como um dispositivo de arquivo, que 
carrega a representação de maneiras de ler o discurso de violência, nas e pelas discursividades arroladas no decorrer da narrativa, tomadas pelo nosso recorte analítico. Nesse sentido, fazemos alusão à perspectiva sustentada por Guilhaumou e Maldidier (2014), que apontam a noção de arquivo como dispositivo que ultrapassa a ideia de textos impressos em série e identificados institucionalmente. De acordo com tais autores, “[o] arquivo nunca é dado a priori, e em uma primeira leitura, seu funcionamento é opaco" (GUILHAUMOU; MALDIDIER, 2014, p.170). Em outras palavras, o funcionamento de um arquivo não é mostrado apenas pela sua identificação institucional. Dito, ainda, de outra maneira o arquivo "é, dentro de sua materialidade e diversidade, ordenado por sua abrangência social. $\mathrm{O}$ arquivo não é um simples documento no qual se encontram referências; ele permite uma leitura que traz à tona dispositivos e configurações significantes" (GUILHAUMOU; MALDIDIER, 2014, p.170).

Vale ressaltar que o problema da violência é demonstrado em vários dispositivos de arquivos. Pêcheux (2014[1982]) nos alerta que há uma divisão social do trabalho de leitura de arquivo em uma relação de dominação política entre o literário e o científico. De acordo com o autor:

a alguns [os literatos], o direito de produzir leituras originais, logo 'interpretações', constituindo, ao mesmo tempo, atos políticos (sustentando ou afrontado o poder local); a outros [os cientistas], a tarefa subalterna de preparar e de sustentar, pelos gestos anônimos de tratamento 'literal' dos documentos, as ditas 'interpretações'... (PÊCHEUX, 2014[1982], p. 60-61).

A partir desse excerto, compreendemos que no tratamento dos textos, a constituição dos dispositivos de arquivos é realizada de maneiras variadas. Por um lado, há leituras legitimadas pelas instituições e, por outro lado, há um confronto demarcado pelas leituras "próprias" dos profissionais da leitura/escritura de arquivos. Dessa forma, as práticas de leitura do arquivo, restabelecidas com base nos seus efeitos nas escrituras, ainda de acordo com Pêcheux (2014[1982], p. 59), “consistiria[m] em marcar e reconhecer as evidências práticas que organizam essas leituras, mergulhando a 'leitura literal' (enquanto apreensão-do-documento) numa 'leitura' interpretativa - que já é uma escritura”. Assim sendo, apreendemos o texto literário como arquivo textual, efeito de leituras, portanto, instala-se na história; implica condições de produção. Nessa medida, interessa-nos o romance $A$ vida é a margem como dispositivo de arquivo que trata, de modo geral, sobre uma questão social global: a violência.

Nessas condições, ponderamos as discursividades procedentes dos recortes que fizemos desse romance, com um olhar para as circunstâncias dadas e, em atenção à língua em usos sociais. É por essa perspectiva que estamos concebendo a narrativa em estudo, como 
materialidade significante em que se opera a circulação de discursividades a partir das quais, considerando suas condições de produção, é possível instituir determinados efeitos de sentidos que constituem os discursos outros, mas que são atravessados por discursos anteriores. No bojo dessas discursividades, são estabelecidos gestos de interpretação possíveis pela inscrição do sujeito em determinadas formações discursivas. Apresentamos, a seguir, nossos gestos de leitura-interpretação.

\section{Violência contra a violência}

Para procedermos ao nosso exercício analítico, vamos circunscrever alguns recortes discursivos (RD) retirados de A vida é a margem, a fim de demonstrarmos representações de e sobre o discurso da violência no Brasil, por meio de discursividades arroladas ao longo da narrativa constitutiva do nosso arquivo em questão. Para começar, abordamos algumas formas de violência que envolvem os trabalhadores do campo. O enredo da história motivadora deste trabalho pode ser sintetizado, simplificadamente, em uma luta entre um coronel e os posseiros por um pedaço de terra. Os fatos e as falas dos personagens são (de)marcados pela maneira árdua em que ocorrem os acontecimentos da trama. A primeira página do romance é aberta com um combate entre o protagonista Seu Sá, "homem sem educação, sessenta e dois anos de idade, de vida, de resistência" (LUZ, 2006, p. 19) e os elementos da natureza. Consideramos, a seguir, o recorte discursivo (RD1) pelo qual nos referimos:

(RD1): O galho verde não resistia ao tinido metálico. Entregava-se sem resistência. O matagal não fugia, as pernas lhe faltavam. Caíam por terra os pés delgados de imbaúbas juntamente com os oitis alastrados em toda a região do Bico-do-Papagaio. A foice sem senso, via todos se rendendo, se dobrando aos pés de quem a manejava. (...)

Estranho ao duelo, o velho entrou na capoeira, deixando no rastro uma clareira de vítimas de diversos tamanhos, idades e cores. $\mathrm{O}$ mato esguio, mole, insistia. A foice assassina devorava impune, na luta pela sobrevivência, só a vegetação perdia (LUZ, 2006, p. 19-20).

Como podemos perceber pela sequência linguística apresentada no RD1, o modo como a história começa sendo narrada, viabiliza a compreensão da violência concebida como processo discursivo, compondo o "espaço" principal de discursivização no romance em tela. A agressividade com que o Seu Sá vai limpando o pasto, como na formulação: “derrubando o mato" (LUZ, 2006, p. 19), anuncia o panorama central da narrativa: a violência. De acordo com o que podemos observar, é no Bico-do-papagaio, no sertão do Tocantins que a violência da foice - instrumento que serve para o trabalho e para defesa do sertanejo - ao cortar a resistente 
mata, prenuncia as próximas condições da narrativa. Esses fatos narrados filiam o texto ao discurso da violência. $\mathrm{O}$ acontecimento pelo qual se origina e se desdobra toda a história institui-se por meio da ameaça que o coronel faz aos pequenos proprietários de terra (denominados de posseiros, por ocuparem a terra, mas não terem sua documentação). Em nosso gesto de leitura entendemos, a partir da história contada, que essa ameaça consiste no fato de eles terem que abandonar suas pequenas propriedades para que o coronel tome posse delas, numa ação de coerção e roubo.

Essa ação, para usarmos um termo comum na sociedade da época, trata-se da grilagem. Neste espaço, consideramos relevante explicar esse termo: ele se refere a uma prática antiga de envelhecer documentos forjados para conseguir a posse de determinada área de terra. Os papéis falsificados eram colocados em uma caixa com grilos. Com o passar do tempo, a ação dos insetos dava aos documentos uma aparência envelhecida. Efetivamente, a nosso ver, o fato de grilar documentação de terras não surgia sem a violência. Esta circunscrição faz trabalhar a memória discursiva em que opera discursividades de que a obtenção da posse de terras é para aqueles que são desonestos e, portanto, usam a força - física ou social - para consegui-la.

A resistência de Seu Sá contra os desmandos do coronel pode ser observada logo quando o posseiro procura o delegado da cidade, objetivando denunciar tais ações. O diálogo é construído pela força e autoridade discursiva e simbólica, como podemos entrever a partir da leitura-interpretação do RD2 a seguir:

(RD2): - Doutor, o coronel, que não sabe o que tem, tá tomando nossa terra. O que o senhor pode fazer?

- Dar conselho, que tal?

O delegado tirou a arma da gaveta pôs sobre a mesa. Nessas horas difíceis, nessas horas em que as coisas da gente querem se acabar, um conselho ajuda demais, principalmente se ele é da polícia.

O velho Sá conseguiu encarar o delegado, nunca tinha feito isso.

- Pois bem, doutor, dê o conselho...

O delegado falou no mesmo tempo.

- Vão para casa, arrumem os trens e venham para cidade. Aqui num tem demanda. $O$ velho Sá alterou-se.

(...) não vou me sujeitar a mais nada. Nem ao homem, nem à lei, nem ao destino. Vai ser olho-por-olho, dente-por-dente. (LUZ, 2006, p. 29-30).

Pelo RD2, é possível apreender a maneira negligente e intimidadora com que os posseiros foram tratados, demarcada, sobretudo pelas seguintes formulações: "dar conselho, que tal?" e “o delegado tirou a arma da gaveta pôs sobre a mesa". Pela nossa perspectiva, a descrição do modo como o delegado oferece o conselho, pondo a arma em cima da mesa e, logo dá como sugestão de resolução do problema, a ideia que Seu Sá abandone sua propriedade, nos permite salientar que a violência se faz, não apenas com agressões físicas. Mas há, também, 
uma maneira coercitiva, psíquica de agredir o outro. Tais formas de violências, a nosso ver, funcionam ao longo da narrativa, muito mais do que indícios e anúncios de possibilidades.

Retomando o fio condutor do enredo da história em investigação, a partir do momento em que Seu Sá e os outros posseiros se negam a abandonar suas terras, para ceder ao aumento da propriedade do coronel, "que nem sabe o que tem", podemos observar que a ameaça advinda da parte do Seu Sá, notável pelas formulações mostradas no RD2, "vai ser olho-por-olho, dentepor-dente", são pronunciadas e, efetivamente, são executadas. Como de fato é mostrado no terceiro capítulo do romance. Essa compreensão se sustenta na medida em que as discursividades produzidas nesta circunscrição filiam-se a sentidos ancorados na memória de que, no sertão, é de praxe as pessoas cumprirem o prometido, isto é, honrarem com as suas palavras. Assim sendo, um acordo é seguramente válido, portanto, considerado verdadeiro. Uma ameaça, então, raramente não seria executada.

De outro lado, o delegado, entre outras possibilidades de negociação entre o coronel e os posseiros, apresenta apenas uma: os posseiros devem sair de suas terras. Em uma relação que aproxima Seu Sá a um bicho, o delegado ainda anuncia a facilidade que seria matá-lo, tendo em vista de que, segundo ele, Seu Sá estava procurando a morte, uma vez que o adversário do velho posseiro, um coronel, era mais poderoso do que ele. Vejamos a seguir o terceiro recorte discursivo (RD3):

(RD3): - As pessoas, os bichos em toda e qualquer situação, têm sempre um jeito de sobreviver, mesmo que a vida não preste, ou esteja tão curta... Mas o que vejo é um homem procurando, correndo atrás da morte, sem saber o que está para trás ou que está pela frente, sem saber o que vai deixar ou o que vai levar... Seu Sá, o senhor fez a pior escolha! Qualquer animal escolheria outra. (LUZ, 2006, p. 30).

O RD3 abre vias para compreendermos que, pelo dizer do delegado, ele atribui a autorresponsabilidade do posseiro ao próprio assassinato. Isso porque optar a não ir para a cidade, para não deixar as terras livres para o coronel, dadas as condições em que vai sendo desenrolada a narrativa, implica a instituição de um combate entre eles. Esse fato nos oportuniza entender que se torna preferível lutar pelo o que se julga ou se deseja ser seu, do que sobreviver. Uma vez que, nas condições de produção da narrativa em estudo, as relações entre os senhores de terras (grandes proprietários) e os trabalhadores do campo (pequenos proprietários) se faz na tensão da luta de classes. Para o delegado, Seu Sá cometeu um erro: escolheu enfrentar o coronel e seu aparato bélico em detrimento da própria vida. Escolha que inclusive, conforme o descrito pela fala do personagem reproduzida no RD3, seria feita por qualquer outro animal. No entanto, o velho se condenou à morte. Dessa forma, a tomada de posição do personagem 
delegado está ancorada à memória inscrita em um repertório discursivo constituído pelo imaginário de que, no Bico-do-Papagaio, na disputa pela terra, a classe dominante é a vencedora, reiterando a ideia de que os posseiros não teriam a menor chance de sobreviver a esse embate.

A partir dessa compreensão, o modo como a tomada de consciência de Seu Sá ocorre sobre a discursividade que "não se luta com o mais forte ou olha no olho de quem pode nos destruir...” (LUZ, 2006, p.30), é marcada pela constatação da ausência da foto de uma autoridade na parede da delegacia. Depois de descobrir que estavam em exposição os retratos do governador e do presidente, o posseiro Belizar - amigo de Seu Sá - observa a falta da foto do prefeito. Vejamos o RD4:

(RD4): O soldado que observava o silêncio de Belizar, aproximou-se:

$-\mathrm{O}$ que foi? Nunca viu autoridade?

- Não, não senhor - disse o posseiro.

- Pois então admire e ajoelhe, um é o presidente, o outro é o governador.

- O prefeito não tá na parede? - questionou Belizar.

- Não, aquele miserável tiramos! - exclamou o soldado acedendo um cigarro. - Ele num paga ninguém vivo.

- Que é isso, soldado! - gritou o delegado. - Bico calado, tu tá conversando demais. (...)

Na porta, [Seu Sá] parou, voltou-se para o delegado.

- Eles estiveram aqui primeiro, não tiveram?

- Não há o que possa fazer. Me admiro muito, vocês já têm tanto tempo de vida e ainda não sabem como ela funciona. (LUZ, 2006, p. 31).

Tomando como referência o RD4, destacamos a formulação "eles estiveram aqui primeiro, não tiveram?”, pela qual é possível compreender que há relações de corrupção entre o coronel e o delegado. Ao passo que, na luta pela propriedade, os posseiros se agrupam em possibilidade de resistência. Em uma resistência que se constrói pelas afinidades de amizade, de companheirismo. Nesse sentido, a violência aparece como forma de solução, capaz de encerrar outra violência.

Dito de outro modo, para os posseiros, a violência que os coronéis estabelecem contra os trabalhadores do campo será combatida por meio da prática de outra violência. Nessas condições, não há espaço para uma negociação, qualquer possibilidade de diálogo surge rechaçada antes mesmo de se pensar uma resolução por esse caminho. Nos recortes, RD2, RD3, RD4, podemos verificar que a probabilidade de mediação pelo Estado (juiz, delegado), é logo descartada, restando apenas a violência como saída para a resolução do problema. Nessa mesma direção, a estratégia do coronel foi contratar pistoleiros para construir um exército particular, como podemos notar pelo recorte (RD5) a seguir:

(RD5): - Os pistoleiros tão chegando!!!... 
Belizar ajeitou-se atrás, preparou o espírito, a arma há muito tempo estava pronta. Tinha que dar o primeiro tiro. Nervoso, resguardava a vida como quem pudesse se livrar da morte.

(...)

Os pistoleiros demoravam, a espera dava sono. Ao longe, escutavam-se as primeiras pisadas. Os cavalos vinham lentos. Em seguida, o bando aparecia morosamente, tão calmos, que pareciam ir para uma festa. Caveira surgiu primeiro à frente de seus pistoleiros. Tudo estava pronto. As bocas dos posseiros salivavam. Caveira, com a espingarda amarrada nas costas, apressava os homens. $\mathrm{O}$ velho acompanhou o inimigo com a arma, endireitou o corpo, prendeu a respiração, aparteou o gatilho. O pistoleiro caiu sem tempo de pegar a arma, sem tempo de proteger-se. Os pistoleiros se espantaram com o flagrante. (LUZ, 2006, p. 43-44).

Nesse espaço, a narrativa caminha lenta, quase sonolenta, como o esperar pelos pistoleiros. Como podemos ler no RD5, a surpresa e o assassinato de Caveira, na tocaia, se dão com orações coordenadas e curtas. A descrição se mistura à narração, abrindo espaço de tensão. A violência está na exposição dos detalhes como se pode ver pelas formulações "as bocas dos posseiros salivavam"; "endireitou o corpo, prendeu a respiração, apertou o gatilho". O descrever da tocaia caminha lento como a guerra. A violência (embate) passa, efetivamente, a ser a resposta à outra violência (ameaça). Porém, esse modo de (re)agir também se constitui como uma forma de resistir à agressão dos opressores, em primeira instância, os donos do poder.

Entre embates e revanches, a narrativa segue. O coronel com seus pistoleiros lutava contra os trabalhadores. A violência contra a violência gera, na primeira batalha, a vitória dos posseiros. Em descontentamento com esse resultado, o coronel quer mais que revidar, quer se apoderar das propriedades dos posseiros e o assassinato deles é o meio. Retomamos, pela leitura do RD5, a memória discursiva que faz trabalhar o imaginário da classe dominadora (os latifundiários) como detentora do poder e, de que no sertão os problemas são resolvidos em batalhas físicas em que alguém deve perder a vida.

\section{Da violência contra os homossexuais}

Para continuar a nossa análise, neste tópico, tecemos algumas considerações sobre as discursividades que dizem respeito à homofobia. Para tanto, selecionamos os seguintes recortes:

(RD6): “- Grinaldo, pegue as munições - disse o coronel.

- Pra que isso?

- Pra gente se vingar. Os nossos homens foram mortos.

O coronel olhou inconformado para o perfil do filho. Coçou a barba.

- Acho que o dia eu morrer, tudo o que consegui, tudo o que lutei pra manter, vai se acabar... Porque esse cabra não passa de um viado.

Grinaldo parou e grudou os olhos no pai.

- O que tá olhando, miséria ruim? - Continuou o coronel. - Nunca me viu?

Grinaldo retirou-se sem falar. (LUZ, 2006, p. 47). 
(RD7): - Coronel! Coronel! O seu filho é viado. Nós pegamos ele no repente.

- Como é?

O velho levantou bruscamente da cadeira.

- Coronel, meu querido patrão. Me desculpe, mas o seu filho tá perdido! O senhor viu? Nem me deixou entrar.

- Cabra ordinário, se tu não retirar o teu atrevimento pode dar adeus à vida. (LUZ, 2006, p. 48).

(RD8): O coronel descontrolou-se:

- Agora, seu filho da puta, levanta, senão te meto uma bala na testa, seu viado... O coronel descontrolou-se pela vergonha que o filho fizera diante dos pistoleiros. Grinaldo tentou correr, mas o velho cinturão de couro dissolvia nas costas. Na sala todos riam, até mesmo Gonçalves que a pouco era zombado pela tropa.

(LUZ, 2006, p. 52-53).

Os RD6, RD7, e RD8 deixam entrever o modo pelo qual a homossexualidade é vista por determinado grupo social. Em nossos gestos de leituras, a discursividade homofóbica surge pelas ações dos personagens, como podemos apreender pelas formulações no RD6: “O coronel olhou inconformado para o perfil do filho. Coçou a barba."; no RD7: "O velho levantou bruscamente da cadeira"; e no RD8: "O coronel descontrolou-se" (bateu no filho com um cinturão de couro). Do nosso ponto de vista, a maneira como o pai (coronel) olhava, agredia e os empregados riam e cochichavam sobre o personagem Grinaldo assinala o preconceito em relação aos homossexuais. À medida que os personagens agressores apresentavam formas de rejeição a todas as ações de Grinaldo, questionando sua capacidade de ser valente diante do enfrentamento contra os posseiros.

Em vista disso, o fato de o rapaz não se interessar por armas, lutas ou vinganças, abriu vias para que os demais personagens afirmem, pelas suas falas no decorrer da narrativa, que Grinaldo era "viado". Isso podemos observar pelo RD6: "porque esse cabra não passa de um viado.”; no RD7: “o seu filho é viado!"; e no RD8: “(...) seu viado...”. Essas formulações são significantes que marcam as discursividades sobre a violência contra os homossexuais, de modo que "resgatam" pela memória discursiva, o imaginário social sobre alguns perfis da homossexualidade, sobretudo no que se referem ao não conseguir manusear armas de fogo, não ter expertise em duelar e não bater em mulher.

Outro ponto a se considerar pelo próprio RD7 é a negação da existência de um homossexual na família, que irá esconder o fato para a sociedade. Como podemos ler também no RD6, em que o coronel, de modo agressivo, afirma que o filho é "viado", no entanto, quando o seu empregado faz a mesma afirmação, ele se aborrece. Aquilo soa como ofensa para ele, a ponto de o coronel ameaçar o pistoleiro (RD7): “cabra ordinário, se tu não retirar o teu 
atrevimento pode dar adeus à vida.". O coronel pode dizer, mas as outras pessoas, não. Essa negação oferece base para o nosso entendimento de que a homofobia começa no seio familiar, espaço em que reverbera uma memória do protótipo de família constituída por um pai, uma mãe e filhos(as). Não havendo, portanto, lugar para outros modelos de composição. Dessa maneira, que não há espaço para um homossexual que, possivelmente, não dará continuidade a esse legado familiar. Vejamos:

(RD9): Na cidade, Grinaldo, alheio a tudo, tentava cumprir com muito sacrifício o desejo do pai. (...)

- Eu quero uma mulher.

- Grinaldo entrou, batia a mão no balcão, num tique nervoso. (...).

- Pai! Pai! Pai! Tá aqui, vou me casar!

Com um gesto positivo apontou a visitante na garupa.

O pai, orgulhoso, correu para a casa, chamando a quem pudesse ouvir. (...)

Todos corriam para a porta, queriam conhecer a esposa do filho do coronel. Os dois herdeiros do latifúndio aproximavam da porteira. (...)

- Parem! - o coronel cortou a discussão e ordenou: - Grinaldo, você trouxe a mulher, muito bem. Agora desce e dê uma taca pra ela aprender a respeitar homem. Depois traga pra dentro e dê comida. (...)

- Pai, não carece... ela vai se comportar, não vai Eleusa? (...)

Sem que ninguém esperasse, nem mesmo Grinaldo, ela pulou do cavalo e empurrou a mão na orelha dele. (LUZ, 2006, p. 79-81).

Como observamos no RD9, Grinaldo é obrigado pelo pai a conseguir uma mulher. O que fará com que ele roube a prostituta Eleusa, para com ela constituir uma família. Além disso, ele deve mostrar que tem autoridade sobre a futura esposa. Para tanto, precisa dar "uma sova nessa rapariga" (LUZ, 2006, p. 80). Contudo, Grinaldo não corresponde às expectativas paternas, tentando negociar a necessidade dessa agressão. Na inflexibilidade do pai, ele acaba por apanhar de Eleusa. Esse fato marca por definitivo a certeza do coronel sobre a sexualidade do filho, que, por seu lado, passa a ser obrigado a aceitar-se como homossexual. Ao apanhar de uma mulher, Grinaldo vê desfazerem-se quaisquer possibilidades de conquistar o respeito almejado: “Agora é tarde, Nega. A vida não tem sentido. Você não vê?” (LUZ, 2006, p. 82). A confissão feita à Nega, empregada da fazenda e sua protetora, parece fazer mais sentido páginas depois, quando a fazenda do coronel é atacada pelos posseiros. Grinaldo não esboça fuga ou contragolpe, ao contrário, como em sacrifício, ele aguarda a morte. Vejamos pelo RD10:

(RD10): Grinaldo, debaixo da sombra das mangueiras, olhava fixo para o tempo. - Os posseiros estão aqui. Saia depressa! Foge, Grinaldo, foge! Eles vão te matar. Grinaldo olhou para a amiga. Gesticulou como se pedisse calma, manteve-se no mesmo lugar com os olhos firmes; riu, momentaneamente, enxergando os posseiros. Achou engraçado os homens tentando matá-lo. Os posseiros atiraram. O corpo vencido foi gratificado com bala. Grinaldo tentou se despedir da amiga e olhou-a sem graça. Nega abraçou o corpo que caía sem forças. O mesmo riso que dera aos posseiros, deu à Amiga.

- Engraçado... em vez da gente ir, a gente regressa. A vida é a margem... - Grinaldo calou-se. (LUZ, 2006, p. 84). 
A cena do assassinato de Grinalaldo (RD10) deixa entreve potenciais leituras, que marcam desde a violência no campo, ao homossexual, bem como uma provável autopunição. Por outro lado, sua morte pode ser lida também como certa resistência aos valores machistas, como se pode ver pelas últimas palavras que pronuncia: "A vida é a margem...”. Estar a margem na vida, se colocando deslocado desses valores violentos, é a possibilidade de encontrar a vida no avesso: "em vez da gente ir, a gente regressa".

\section{Da violência contra a mulher}

Em conformidade com os gestos de leitura-interpretação que vimos circunscrevendo, para versarmos sobre as discursividades que evidenciam representações da violência contra a mulher no romance em estudo, registramos apenas dois recortes. Iniciamos com o primeiro que mostra a venda de Anita, filha do Seu Sá. Tratada como uma mercadoria pelos negociantes, ela foi oferecida pelo pistoleiro Pedrão ao coronel e, logo em seguida, trocada por trinta cabeças de gado, conforme o recorte discursivo (RD11), a seguir:

(RD11): - Eu tenho uma coisinha que vai deixar o senhor alegre - falou baixo, quase no ouvido.

O coronel parou de balançar a cadeira, temperou a goela e escarrou. O cuspe voou sobre a areia.

- O Senhor tá com fôlego bom hein, coronel...

- Então fale! Deixe de rodeio.

- Anita!

- Que diabo tá dizendo?

- Anita, a filha do velho Sá, já deve ter uns treze ou quatorze anos, num tem mãe e tá lá em casa, tamo cuidando dela. Então pensei que o coronel bem que poderia se interessar por aquela moça. Ela vai lhe dar muita alegria. É só o senhor dá uma ajuda e pronto, é sua...

(...)

- Quer quanto?

(...)

Eu faço, pro senhor, por trinta vaquinhas. E, em vista da mercadoria, isso não é nada, coronel!

O pistoleiro [Pedrão] se retirou; Nega encarou o patrão:

- O senhor não devia ter aceitado a criança, ela não tem culpa de nada.

- Se não pude ter a mãe, agora posso ter a filha. Fiz um negócio bom, isso é o que importa. (LUZ, 2006, p. 90-91).

Pelo RD11, entendemos pelas formulações, "o senhor tá com fôlego bom hein coronel...", "ela vai lhe dar muita alegria" e, ainda, "se não pude ter a mãe, agora posso ter a filha", que a negociação de Anita marca fortemente o lugar que o corpo feminino é narrado. Como podemos observar pelas sequências linguísticas acima, para convencer o coronel, Pedrão usa argumentos como "já deve ter uns treze ou quatorze anos", que, pelo nosso ponto de vista, sugere a aptidão da menina para a prática sexual e, ainda, por ser tão jovem, a violação de um 
corpo virgem. Essa cena marca o olhar diferenciado dos homens (Pedrão e o coronel) e da mulher (Nega). Por um lado, para Pedrão, há uma possibilidade de alegria e prazer, que uma moça seria capaz de proporcionar a um homem. Sobretudo, para ele, Anita possui um valor de mercadoria (trinta vaquinhas). No que concerne ao coronel, além de compartilhar da objetificação da menina, ele a vê como oportunidade de suprir o seu desejo de juventude que não fora realizado, visto que ele queria se casar com a mãe de Anita, que optou por outro marido (Seu Sá).

Sendo assim, compreendemos que ambos veem a moça como negócio e propriedade. Por outro lado, Nega, mesmo vendo que houve uma negociação, não aceita o fato, dizendo que o coronel não deveria ter feito essa troca. Ademais, diferente dos homens, ela chama Anita de criança, o que nos permite refletir sobre um modo que Nega tem de enxergar a menina, ou ainda de retirar esse olhar pelo âmbito da sexualidade, que os homens obtiveram de Anita. A cena da chegada da filha do velho Sá reforça a negociação, na qual os únicos elementos a serem considerados são as partes físicas sexualizadas - nádegas e pernas - de Anita, como podemos observar pelo recorte discursivo (RD12), a seguir:

(RD12): Pedrão chegou ao amanhecer trazendo a menina. O coronel esperava-a, arrumando-se, tentando ficar bonito.

- Vem pra cá, quero te ver de perto.

Anita foi empurrada até o local em que se encontrava o latifundiário.

- Roda ela, eu quero vê atrás.

Pedrão rodou a menina, apontou para o traseiro.

- É boa ou não é? Olhe a belezura dessa anca.

$\mathrm{O}$ velho aprovou com um riso silencioso. Aproximou-se, ficou de frente à menina, agachou-se olhou para as pernas. Pegou nas canelas e levantou as mãos até o joelho apalpando firme as pernas trêmulas. Com as pontas dos dedos acariciou suavemente os contornos da coxa. Levantou-se e olhou para Pedrão.

- Tá tudo certo. Pode ir para o curral. Ela vale. (LUZ, 2006, p. 95-91).

O RD12 viabiliza a compreensão de que não há qualquer possibilidade de a menina ter voz, de haver um espaço de negociação. As sequências linguísticas apresentadas nesse recorte como na formulação: “- tá tudo certo. Pode ir para o curral. Ela vale”, tanto pela construção de falas curtas e certeiras do personagem, como pelo uso de palavras de afirmação, nos autoriza apreender que não há condição para outras possibilidades que não seja a venda de Anita. O seu corpo é apenas objeto e, desse modo, é fragmentado, como já mencionamos, em partes sexuais. Nesse segmento, recortamos a cena que demarca a cultura do estupro, de acordo com o RD13, a seguir:

(RD13): Mordeu a mão do coronel e debandou-se a correr.

Porém, seu algoz, enfurecido, puxou-a para o quarto.

- Eu transei, trepei, comi tua mãe! Ela não me deu tanto trabalho... 
O velho fechou a porta, jogou-a em cima da cama. A menina atordoada, pasma, encarava aquilo com quem encara a morte... Sem opção de fugir. O coronel tirou o cinto, perdurou tudo, cobrindo o revólver. A menina vulnerável, se perdia, se fragilizava.

- Se acalme... Vai ser muito bom! Ela levantou-se, quase correndo.

- Vem cá!

O velho sempre mais rápido, mais dominador. Agarrou-a como quem a abraçasse. Jogou-a na cama, no mesmo impulso pulou em cima. Anita reagiu, chorou, gritou. Até render-se à força do coronel. (LUZ, 2006, p. 96-97).

A cena descrita no RD13 nos emudece. Nesse espaço, a narrativa de Josué Luz nos autoriza, pela nossa filiação ideológica, a encerrar qualquer possibilidade de análise. Mas não o fazemos. O efeito de transparência da linguagem marca o tom "evidente" da agressividade da cena. É quase impossível não dizer sobre a violência no corpo da criança Anita. A partir dessas considerações, pensamos na literatura como dispositivo de arquivo capaz de suportar diversos gestos de leitura. Tais gestos de leitura, para um grupo de sujeitos filiados à memória discursiva inscrita em formações discursivas filiadas ao discurso feminista por exemplo, estão para a ordem do impensável, do intocável, do inadmissível. No entanto, também pela literatura, esses gestos são passíveis de acontecerem, de modo que poderia ser muito dolorido de se enunciar no âmbito de outro dispositivo arquivista.

A narrativa em estudo nos leva a pensar as relações tão dolorosas que enfrentamos, nos dando uma beleza de outra ordem. Retira-nos da realidade para nos colocar na própria realidade. Tanto que A vida é a margem nos conduz à "veracidade" dos fatos, à certa "verdade", não apenas aquela verdade da violência do sertão brasileiro. Porém a verdade que enfrentamos hoje, ainda presos não apenas na pandemia do covid-19, mas nas relações violentas que o Estado provoca sobre os mais desabastados, sobre a violência que tantas mulheres estão sofrendo nesse período de confinamento. Em nossa concepção, a literatura produz textos que nos ajuda a sobreviver.

Em retorno à narrativa, ressaltamos que Anita engravidou do seu estuprador, o qual se tornou seu marido. Como tantos brasileiros e brasileiras, o neto do Seu Sá é fruto de um ato de violência. Ainda no RD13, as formulações, “jogou-a na cama, no mesmo impulso pulou em cima. Anita reagiu, chorou, gritou. Até render-se à força do coronel”, retomam uma discursividade sobre o fato de o homem ter autoridade sobre o corpo da mulher, negligenciando qualquer que seja a sua vontade. Ainda que não desejasse, Anita deveria obedecer ao, agora, marido.

A partir de toda a trama e de formulações como "é costume no sertão, a mulher ter duas funções, a de parir e a de servir ao homem" (LUZ, 2006, p. 36), podemos fundamentar a 
produção do efeito de sentidos para as sequências linguísticas supracitadas. Esse funcionamento faz "retomar" uma rede de memórias de que a mulher deve ser submissa ao homem. A partir desse entendimento, sem perder de vista a sua inserção entre os discursos de violência, tornase plausível salientar que o discurso machista é constitutivo dessa discursividade.

O final do romance é feito de um duelo que marca o fim trágico dos personagens, Seu Sá e o coronel. A nosso ver, há uma tentativa de se compor certa moral para a história, sobretudo, quando o coronel arrisca sua vida por amor ao filho, recusando, inclusive, uma possibilidade de tratamento pela feitiçaria de Nega. Ademais, ter como herdeiros de toda sua propriedade a filha e o neto de um posseiro pode criar, ainda que, simbolicamente, a violência como possibilidade única para as minorias.

\section{Considerações finais}

Entre tantas formas de violência, iniciamos este trabalho registrando o modo violento em que o Estado tem tratado o povo brasileiro, no que se refere aos investimentos necessários para o desenvolvimento de programas sociais e educacionais do país. Nessa conjuntura, o que temos vivenciado são os cortes de verbas e a negligência das autoridades competentes frente à essa situação. Somada a isso, temos ainda uma pandemia, que vem se estendendo há mais de um ano por todo o mundo. Sobre essa questão o governo brasileiro tem se mostrado ainda mais omisso, ignorando o número de mortes e não dando assistência efetiva para o povo e para os profissionais da linha de frente do SUS, que arriscam suas vidas - entre tantos que já perderam - e a vida de suas famílias todos os dias em seu exercício laboral.

Dessa maneira, no decorrer deste artigo, partimos do nosso cenário social para articularmos essa temática, a violência no Brasil à outra "realidade", a da literatura. Nesse sentido, buscamos mostrar marcas de discursos de violência representados pelas discursividades apresentadas ao longo do romance $A$ vida é a margem, nas circunstâncias das práticas sociais em que se envolvem os seus personagens. A partir desse romance, pudemos lançar um olhar para diferentes maneiras de (re)constituição dos discursos de violência mediante formas diversas de (re)formulação de discursividades de e sobre a violência no Brasil. Dessa maneira, na medida em que concebemos o romance em tela como dispositivo de arquivo, apreendemo-lo, como um meio de circulação desse discurso, especialmente, no que se refere à violência existente no interior do país, mais especificamente, no sertão do Tocantins, o cenário de toda a trama narrativa. 
Voltamos a nossa atenção para a representação de discursos de violência, tais como a violência no campo, a violência contra a mulher e a homofobia, a partir dos recortes que selecionamos da narrativa de Josué Luz para compor o nosso corpus analítico. Cabe lembrar que consideramos a opacidade constitutiva da linguagem. Nesse sentido, compreendemos que a narrativa não se impõe de forma absoluta. Ela não é transparente. Assim, a narrativa não se fecha como um todo. Nessa esteira, vimos em Pêcheux (2014[1982]) que o arquivo possui uma leitura subjacente pela sua própria organização, colocando em jogo gestos de interpretação que podem direcionar efeitos de cristalização a determinados sentidos. No entanto, a cada (re)tomada desse arquivo, novos gestos de leitura são possíveis. Tais gestos de leitura se fazem pela tomada de posição assumida pelos sujeitos.

Com efeito, reiteramos que a tomada de posição é feita a partir da interpelação ideológica do indivíduo em sujeito. Assim, é na e pela ideologia que os sujeitos se filiam às formações discursivas, nas quais a memória trabalha formulações anteriores, portanto, a constituição dos sentidos é ideológica. Por conseguinte, o arquivo como efeito da memória discursiva configurada pelo conjunto de textos que o compõe, já estabelece, de certo modo, o direcionamento dos sentidos. Há uma relação entre saber e poder social definindo os modos de apropriação dos discursos.

As discursividades apresentadas a partir dos recortes que utilizamos para a nossa análise revelam um modo de funcionamento que faz retornar uma rede de memória, pela qual, ressoam diversas vozes da e sobre a violência, de modo que pudemos circunscrever, pelos RD descritos, efeitos de sentidos inscritos em formações discursivas instituídas ideologicamente. Nessa medida, compreendemos que a constituição do arquivo coloca em jogo gestos de interpretação, apresentando leitura(s) determinada(s) em detrimento de outras leituras possíveis. No entanto, essa constituição não é estática, uma vez que, essas novas leituras possíveis tornam-se plausíveis a cada (re)tomada desse arquivo.

\section{Referências}

INDURSKY, Freda. Memória e cena do discurso. In: INDURSKY, Freda; MITTMANN, Solange; FERREIRA, Maria Cristina Leandro. (Org.). Memória e história na/da análise do discurso. Campinas, SP: Mercado de Letras, 2011.

LUZ, Josué. A vida é a margem. Goiânia: Kelps, 2006. 
ORLANDI, Eni P. Discurso e texto: formulação e circulação dos sentidos. 4. ed. Campinas, SP: Pontes Editores, 2012.

ORLANDI, E. P. Análise de discurso: princípios e procedimentos. 12.ed. Campinas, SP: Pontes Editores, 2015.

PÊCHEUX, Michel. Análise automática do discurso (AAD-69). In: GADET, Françoise; HAK, Tony. (Orgs.). Por uma análise automática do discurso: uma introdução à obra de Michel Pêcheux. 5.ed. Campinas, SP: Editora da Unicamp, 2014 [1969].

PÊCHEUX, Michel. Semântica e discurso: uma crítica à afirmação do óbvio. 5. ed. Campinas, SP: Editora da Unicamp, 2014 [1975].

PÊCHEUX, Michel. Ler o arquivo hoje. In: ORLANDI, Eni et al. (org). Gestos de leitura: da história no discurso. 4.ed. Campinas, SP: Editora da Unicamp, 2014 [1982].

PÊCHEUX, Michel. Papel da memória. In: ACHARD, Pierre et al. (org). Papel da memória. 4.ed. Campinas, SP: Pontes Editores, 2015 [1983]. 